\title{
Water supply regulation in Nigeria: problems, challenges, solutions and benefits
}

\author{
Olajumoke Rukayat Balogun, Marina M. Redina \\ Peoples' Friendship University of Russia (RUDN University) \\ 6 Miklukho-Maklaya St., Moscow, 117198, Russian Federation
}

\begin{abstract}
Even though Nigeria is recognized for her rich vegetation and tropical weather and blessed with surplus water resources, the country still faces challenges on getting clean water supply around the country and mostly depend on alternative water supply like well, borehole and river. These alternative water supply systems are not efficient and viable enough for water supply systems especially in a country with large population. The country is characterized by irregular water supply and water management laws are also weak and mostly not in conformity with today's standard and needs. Proper management and conservation of the water supply services and resource has not given adequate attention by the government. It is, therefore, important to identify such factor that inhibits the implementation of water regulations and proffer a solution to these. In a bid to provide an understanding of the effect of implementing and enforcing stringent water regulation and providing adequate water supply, we compare forecasted population with investment capital expenditure (CAPEX) for water supply by Millennium Development Goal (MDG+) targets. The result shows that in year to come, the country will significantly benefit from investing and providing regular water supply through employment availability and revenue generated through utility water bills, spending less on epidemic of water-borne diseases thereby improving the lives and health of its citizen.
\end{abstract}

Keywords: water supply; regulations; implementations; investment; benefits

\section{Introduction}

Water is a terminable resource that is very essential for human existence, agriculture and industry. Without doubt, inadequate quantity and quality of water supply have a serious impact on water resources management and environmental sustainability. Suitable environmental policies are a foundation for a friendly and healthy society. They play an important role in the wellness and the development of a nation by enforcing stringent rules that ensures preservation and protection of the environment. Nigeria as a nation is rich in natural resources which includes water resources, the environment is an important source for its national and economic development, it is, therefore, important to protect the environment from degradation or pollution.

(C) Balogun O.R., Redina M.M., 2019

cc (i) This work is licensed under a Creative Commons Attribution 4.0 International License https://creativecommons.org/licenses/by/4.0/ 
The country is facing a lot of challenges on environmental pollution, deforestation and erosion, emanating from activities of its individuals, industrialization and urbanization. Individual activities such as improper disposal of waste, deforestation and the use of toxic chemicals on both plants and water are gradually causing serious damage to the atmosphere (hydrosphere and lithosphere) which are essential for the survival of both plants and human existence. Industrialization and urbanization are also a major contributor to the generation of environmental pollutions, hazardous and non-hazardous. Industries such as oil companies, pharmaceutical, cement, food and beverages, plastic, textile, etc. are posing a serious threat to the sustainability of the country. The country is increasingly growing in urbanization which is paving room for the establishment of more industries.

The need for environmental control arises from the fact that it brings improved health and better living conditions [3]. Environmental policies are supposed to manage, protect and preserve the environment in which we live. Environmental problems the country is currently facing is as a result of the ineffective implementation of environmental laws. These challenges range from lack of governmental water supply, infrastructure to properly implement those laws, poor governance and corruption to lack of maintenance of facilities that aids its implementation.

\section{Water resources in Nigeria}

Nigeria, with a land area of about $924,000 \mathrm{sq} . \mathrm{km}$, is located within the tropics where its climate is semi-arid in the North gradually becoming humid in the South. The annual rainfall varies from over $4,000 \mathrm{~mm}$ in the South-East to below $250 \mathrm{~mm}$ in the extreme North-East and is subject to significant temporal variation. The surface water resources potential of the country is estimated at 267.3 billion cubic meters while the groundwater potential is 51.9 billion cubic meters [4].

Nigeria has 36 states many of which are so rich in water resources and some of these states were named after rivers. Apart from the surface water found in nearly every part of the country, the country is also endowed with plenty underground water. With a 215 cubic kilometers a year of surface water availability, this amount is much higher than many African countries especially those in the southern and northern regions of the continent. South Africa, for example, has about 49 cubic kilometers a year [5].

The north with low precipitation of only about $500 \mathrm{~mm}$ in the northeastern corner, and the south with precipitation of over $4,000 \mathrm{~mm}$ in the southeast. This high variability of rainfall in time and space is a significant characteristic of the tropical climatic belt, especially the Sahelian part of the country, in which the country is located and this needs to be factored into water resources management in the country [4].

\section{Water system supply and management}

The Federal Ministry of Water Resources (FMWR) is the foremost agency for water, sanitation and hygiene (WASH) activities in Nigeria. The ministry works in together with the National Task Group on Sanitation (NTGS) and development partners on sanitation and hygiene issues. The national standards and targets being 
followed are as stated in the Water Sector Road Map of 2010, the Vision 20:2020, the Millennium Development Goals (MDGs) and the African Water Vision [5].

The primary responsibility for the provision of municipal and domestic water supply is by the state and local governments under the umbrella of the State's Water Corporation. However, the Federal Government often intervenes to increase access in order to meet these targets. Even though monitoring and evaluation of water supply and regulation are not taken seriously enough, there are agencies whose function is monitoring activities in the WASH sector.

However, effective legislation could not be made to ascertain the quality of water supply and management. In compensation with the lack of insufficient quality water supply to the citizen, Alternative market of water production by the private owners (traditional well water and borehole) took over the supply of water in the country.

\section{Water resources regulation mechanism in Nigeria}

The Federal Ministry of Water Resources (FMWR) has authority over all the formulation of national policy and strategy advice for the public provision of water. But, it is up to each state to adopt and implement national legislation and policy, as well as to decide on the institutional framework for delivering services. While the local governments water sectors takes all formulations of policies on managements from their state governments. The National Council on Water Resources (NCWR) is the highest water resources policy formulating body, overseen by the FMWR and with representatives from the Federal Ministry of Environment and all commissioners for state governments. State Ministries of Water Resources are responsible for policy, regulation, and monitoring which are passed down to control the local governments even though not all states have a stand-alone ministry of water resources (e.g., the Rivers State Ministry of Water Resources and Rural Development RSWRRD - in Rivers State). Thus, while certain structures and policies related to water supply prevail throughout the country, there is a great deal of variation in the management and provision of water across jurisdictions [20].

\section{Water regulatory bodies in Nigeria}

Historically, beginning from colonial Nigeria, the Water Works Acts, 1915 is the only pan Nigerian law passed specially to keep water from being polluted. It bans the pollution of water works in Nigeria by noxious or harmful matter or substances. The Minerals Act, 1917 (as amended) bestows the president of Nigeria with power to make regulations for the prevention of pollution of any natural water supply or watercourse. The Public Health Act, 1917 forbids contamination of water and pollution of the atmosphere. It embodied provisions against introduction of harmful substances into the various sources of water supply for human and animal consumption. All these laws were made by the colonial authorities before the attainment of sovereignty [20].

There are several water regulation laws in Nigeria and a summary is given in Tables 1 and 2. 
Statutory bodies for water regulation in Nigeria [12; 20]

\begin{tabular}{|c|c|c|}
\hline No. & Statutory body & Key provision \\
\hline 1. & The Oil in Navigable Waters Act, 1968 & Prohibits water pollution by oil spillage \\
\hline 2. & The Petroleum Act, 1969 & $\begin{array}{l}\text { Covers prevention of pollution by inland waters, rivers, } \\
\text { lakes and watercourses }\end{array}$ \\
\hline 3. & $\begin{array}{l}\text { The River Basin Development Authority } \\
\text { (RBDA) Decree } 25 \text { of } 1976 \text { (repealed by } \\
\text { No. } 87 \text { of } 1979 \text { and also latter by the RBDA } \\
\text { Act, Decree } 35 \text { of } 1987 \text {, i.e. Cap 396) }\end{array}$ & $\begin{array}{l}\text { In its present form Cap. } 396 \text { spells out diverse functions } \\
\text { and objectives for these authorities to ensure a Pan- } \\
\text { Nigerian programme for water resources development }\end{array}$ \\
\hline 4. & $\begin{array}{l}\text { The Environmental Impact Assessment } \\
\text { (EIA) Decree, No. } 86 \text { of } 1992\end{array}$ & $\begin{array}{l}\text { This law seeks to protect the physical and aquatic envi- } \\
\text { ronment }\end{array}$ \\
\hline 5. & Water Resources Decree, No. 101 of 1993 & $\begin{array}{l}\text { Vests the right to use and control all surface waters and } \\
\text { groundwater and of all water in any watercourse affecting } \\
\text { more than one state in the Federal Government, with } \\
\text { provisions that any person may take water without charge } \\
\text { for his domestic or livestock watering purposes (in any } \\
\text { watercourse to which the public has free access) }\end{array}$ \\
\hline 6. & $\begin{array}{l}\text { The } 1999 \text { Constitution of the Federal } \\
\text { Republic of Nigeria }\end{array}$ & $\begin{array}{l}\text { The Constitution puts in the Exclusive Legislative List (ELL) } \\
\text { shipping and navigation on the River Niger and its afflu- } \\
\text { ent and on any such other inland waterway as may be } \\
\text { designated by the National Assembly to be an interna- } \\
\text { tional waterway or to be an interstate waterway. The ELL } \\
\text { also includes water from such sources as may be de- } \\
\text { clared by the National Assembly to be sources affecting } \\
\text { more than one state }\end{array}$ \\
\hline
\end{tabular}

List of other regulations bearing on water resources in Nigeria [20]

\begin{tabular}{|c|l|l|}
\hline No. & \multicolumn{1}{|c|}{ Name of regulation } & \multicolumn{1}{|c|}{ Key provisions } \\
\hline 1. & National Policy on Environment 1989 & Protection of the environment \\
\hline 2. & $\begin{array}{l}\text { National Guidelines and Standards for Environ- } \\
\text { mental Pollution Control in Nigeria 1991 }\end{array}$ & $\begin{array}{l}\text { Pollution control in watercourses as part } \\
\text { of the environment }\end{array}$ \\
\hline 3. & National Effluent Limitation Regulation 1991 & $\begin{array}{l}\text { Control of discharge of industrial waste } \\
\text { and sewage into watercourses }\end{array}$ \\
\hline 4. & $\begin{array}{l}\text { Pollution Abatement in Industries and Facilities } \\
\text { Generating Wastes Regulation 1991 }\end{array}$ & Control of industrial pollution \\
\hline 5. & Waste Management Regulation 1991 & Waste management \\
\hline
\end{tabular}

\section{Water supply agencies in Nigeria}

As mentioned above, however there are numerous regulatory bodies for water regulation in Nigeria. Their enforcement, implementation and service responsibilities are carried out by the government under three main levels: the federal government, state government and local government. 


\section{Governmental water supply services responsibilities}

There are three major level of government that share responsibility for the delivery of water supply services. Whereas the responsibility for sanitation is not always clear, the state government are mostly responsible for sanitation especially in urban areas.

Federal government. The Nigeria Federal Ministry of Water Resources, was part of the Ministry of Agriculture until 2010, is responsible for large water resources development projects and water allocation between states of the federation. There are 12 River Basin Development Authorities under this Ministry, responsible for planning and developing water resources, irrigation work, the collection of hydrological and hydro-geological data and also provide water in bulk to cities from dams [1].

State government. Responsibility for portable water supply is entrusted to State Water Agencies (SWAs) or state water departments in the 36 Nigerian states. The SWAs are responsible to their state governments, generally through a State Ministry of Water Resources. SWAs are responsible for urban water supply, and in some states also for rural water supply. As of 2000, 22 states had separate state-maintained rural water and sanitation agencies, mostly set up to implement a UNICEF program [1;2].

Local governments. The country's Local Government Authorities (LGAs), of which there are 774, are responsible for the provision of rural water supplies and sanitation facilities in their areas although only a few have the resources and skills to handle the problem. Only few LGAs have rural water supply divisions.

\section{Other water supply services}

Communities. In some rural area or rural communities water and sanitation committees (WASCOs) are formed to operate and maintain water facilities. These committees are tasked with the duty of collecting water tariffs from inhabitants of these communities. Donors such as the African Development Bank have set a requirement that at least 30\% of members of WASCOs must be women [6]. In 1993 the government committed itself to reinforce community participation in rural water supply in a policy document which as of the year 2000 but the policy had not been dispersed or administered in all government or donor-financed programs.

Individual water supply services also known as alternative water supply system; mostly everywhere in the country, the residents practice or are engaged in this part of water supply service due to the shortcoming of water supply from the governmental water supply services.

\section{Water supply scheme in Nigeria}

There are several means by which the people in the country get water for their daily needs (Figure 1).

1. Pipe Borne Water. Pipe borne water is provided by State Water Corporation and it has been the primary source of water supply for many years, but due to 
lack of funds and inadequate maintenance, it is not as functioning as it was back and this has led to sourcing for water through alternatives methods.

2. Boreholes. Most common in big urban areas of the country; boreholes are small holes dug by machine into the ground. Also some communities in the rural areas get to have at least a bore water supply built by non-profitable agencies. They range from 100 feet to 200 feet deep and their construction is usually carried out by designated borehole companies. Because of the high price of boreholes, only the rich people can afford to get one in their homes and political office holders and international organization also build boreholes for communities in the country.

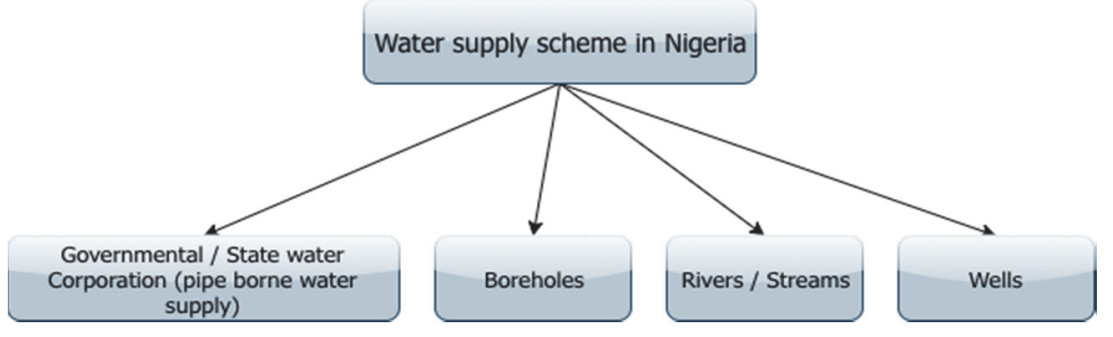

Figure 1. Major water supply sources in Nigeria

3. Wells. Due to inadequate water supply to the masses, the average residents could only afford a well water. A well water is an excavation or structure created by digging into the ground in order to access groundwater.

4. River/streams. In some remote areas of the country where there are no access to pipe borne water and there were not wells, the inhabitant of this places rely solely on water from rivers for consumption.

\section{Problems and challenges}

There are several problems that plague water supply and enforcement of water regulation in Nigeria. In the next section, we discussed some of these problems.

Rural to urban migration. There have been an increase in water supply demand due to high population growth rate coupled with increasing urbanization, and rising living condition as a result of economic growth. The state water corporations all over the country could not meet this demand because the corporation faces a lot of problems such as inadequate funding and monitoring of the projects of the sector has not been carried out on regular basis.

Environmental pollution. The nation's water sources are under serious threat from inadequate catchment management and widespread pollution, including the indiscriminate disposal of hazardous substances. The oil-producing region of Nigeria, the Niger Delta, suffers a lot from the improper implementation of environmental policies and activities associated with petroleum exploration, development and production. They have been experiencing a wide range of environmental degradation and pollution and are at high risk of health hazards and socio-economic problems [7]. These regions often have to deal with oil spillage in their rivers from oil and gas industries thereby causing serious damage to aquatic life and plant as well. Since the environmental policies in Nigeria are not very effective, these communi- 
ties have to deal with these situations by themselves most of the time. Consuming water and plants contaminated with oil is dangerous to health.

Irregular supply of water. In most part of the country, water has been a scarce commodity whereby give no chose to the citizens than to search for another means of water supply for their daily needs and activities. This led to an increase in the rate of alternative water supply in the country.

Lack of stringent environmental regulation. Over the years, threats to the nation's water resources are as a result of poor and uncoordinated management of the resource. Federal and state governments have a much bigger role in the overall management of the nation's water resources. In most cases, stakeholders are not consulted or otherwise involved in planning, development and management of the nation's water resources [11]. The result has been a sequence of unsubstantial projects with lacking services that do not meet consumer needs and thereby leading to the consumers' unwillingness to pay.

\section{Water production rate and problems of alternative water supply systems}

It has become a common practice where almost every building has its own traditional well water and boreholes. This has been the major water supply system every individual rely on for water in the country. The WHO/UNICEF Joint Monitoring Program (JMP) data showed a significant decline in the proportion of households with access to piped water to premises, which dropped from 33 per cent in 1990 to 6 per cent in 2012 [8]. This is as a result of non-utility-improved water sources, such as boreholes in compounds and private households.

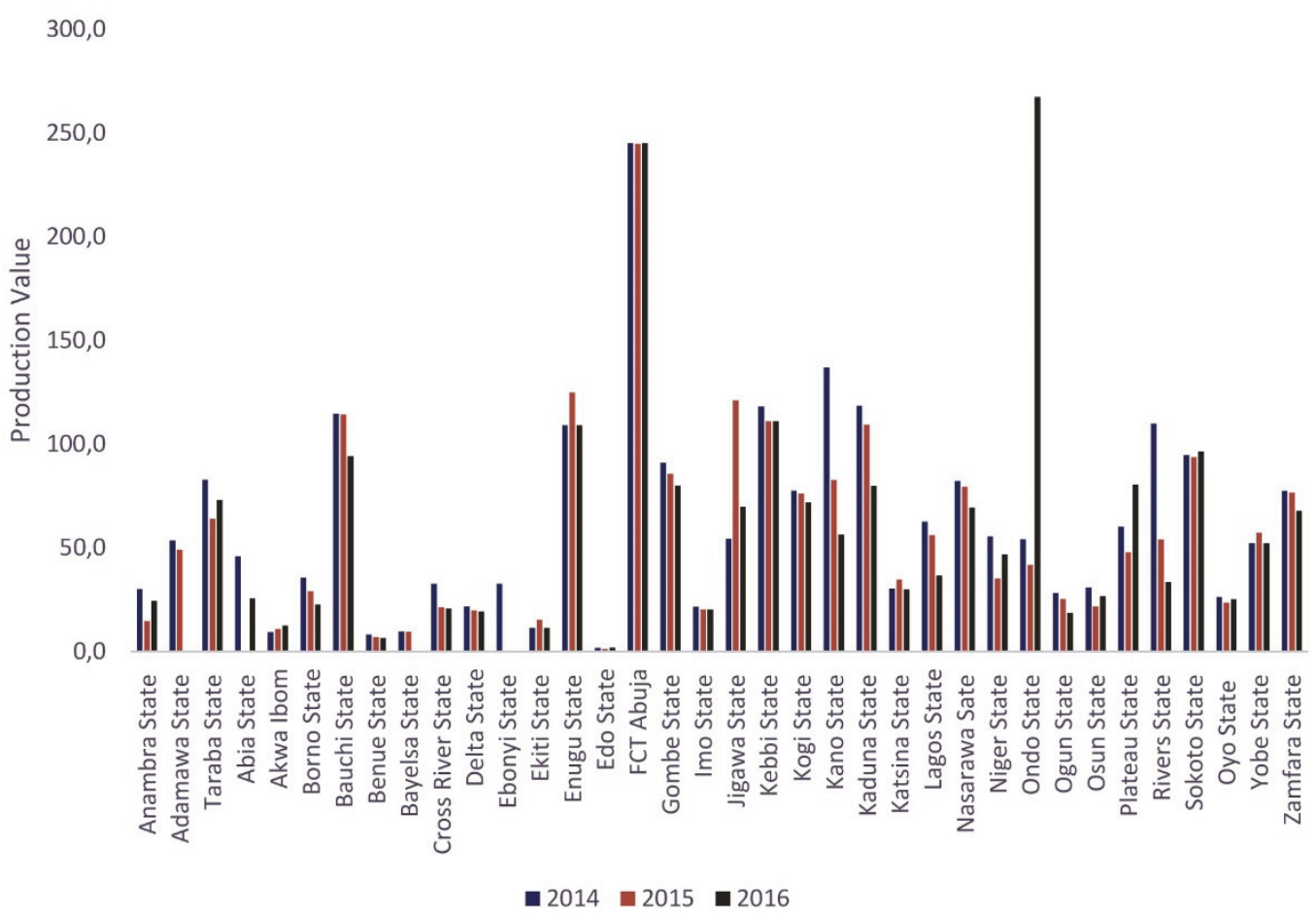

Figure 2. Water production per state 
The graph in Figure 2 above shows the water production per state in Nigeria for the year 2014 to 2016 . It could be seen that water production for some states are drastically reduce with time. Some of the most populated states in the country like Lagos, Kaduna and River States have low water production for 2016 and these states have witnessed an increase in population ever between these years [9].

\section{Solutions to water challenges in Nigeria}

Some solution to the challenges facing water regulations and production in Nigeria are as follows:

- regular update of water regulation laws and policies;

- provision of constant water supply;

- provision of standard infrastructure and water treatment facilities;

- incorporating a standard method of water treatment using the international treatment guidelines;

- enforcing strict compliance to environmental law;

- implementation of new law to reduce the amount of alternate water supply.

\section{Regular assessment of water supply}

For the performance of a community or central water-supply system, a number of factors must be considered. Some countries that have developed national strategies for the surveillance and quality control of water supply systems have adopted quantitative service indicators for application at community, regional and national levels.

These usually include:

1) quality - the proportion of samples or supplies that comply with guideline values for drinking-water quality and minimum criteria for treatment and source protection;

2) coverage - the percentage of the population that has a recognizable (usually public) water-supply system;

3) quantity - the average volume of water used by consumers for domestic purposes (expressed as liters per capita per day);

4) continuity - the percentage of the time during which water is available (daily, weekly or seasonally);

5) cost - the tariff paid by domestic consumer.

Together, these five service indicators provide the basis for setting targets for community water supplies. They serve as a quantitative guide to the comparative efficiency of water-supply agencies and provide consumers with an objective measure of the quality of the overall service and thus the degree of public health protection afforded [15].

\section{Implementations of water regulations}

The aim of national drinking-water laws and standards should be to ensure that the consumer enjoys safe potable water, not to shut down deficient water supplies. 
Effective control of drinking-water quality is supported ideally by adequate legislation, standards and codes and their enforcement. The precise nature of the legislation in each country depend on its national, constitutional and other considerations.

Legislation should make provision for the establishment and amendment of drinking-water quality standards and guidelines, as well as for the establishment of regulations for the development and protection of drinking-water sources and the treatment, maintenance and distribution of safe drinking-water.

\section{Policy challenges}

The Water Decree 101 from 1993 is the principle legislation governing the utilization and pollution control of the water resources. This legislation do not adequately meet present and emerging water resources management challenges and the requirement emerging from this water policy. Thus, the legislation needs to be reviewed in order to address the growing water management challenges [16].

A central issue of a new water legislation will be the definition of access to water resources through permits, the establishment of water protection zones and the fees related to water raw water abstraction and fines for water misuse and pollution. This is to respect the "user-pays" principle. Access and the application of royalties for water abstraction will not be applied in a general manner but limited to the commercial use of water resources only.

\section{Methodology}

In this section, we discuss the methodology used to access the effect of water regulation and production in Nigeria.

Population is one of the most important factors for design of the water systems, so it should be estimated, so as to know the increasing demand and ensure continuous supply to them. Population data is obtained by previous records and the rate of increase is found out and this used for further analysis. Using the geometric method of population forecast in order determine the continuous growth of people in the country [10].

$$
A=P(1+r)^{n},
$$

where $A$ - population at some time in the future that is, nth years' time; $P$ - present or baseline population (190.9 million) of 2018; $r$ - average percentage increase (geometric mean) that is the annual population growth rate (2.6\%) [17]; $n$-period of projection in decade; the number of years from the baseline population year to the future population year of 2020,2030, 2040 and 2050.

Results obtained were 200.114 million, 259.761 million, 335.775 million, and 434.032 million respectively as shown in section "Results and discussions".

This method assumes that the percentage of increase in population from decade to decade is constant. This method gives high results, as the percentage increase gradually drops when the growth of the cities reach the saturation point. This method is useful for cities which have unlimited scope for expansion and where a constant rate of growth is anticipated.

Capital expenditure, or CAPEX, are funds used to acquire, upgrade, and maintain physical assets such as property, industrial buildings, or equipment. It is 
often used to undertake new projects or investments by the firms. This type of financial outlay is also made by companies to maintain or increase the scope of their operations. Using the Drinking Water Supply in Nigeria: Transforming Funding to AEPA Services, the capital investment (CAPEX) is required annually to meet the water supply MDG+ targets estimated of US \$1,716 million per year for Nigeria. We can calculate the current CAPEX per current population [14].

Current CAPEX per current population $=\frac{\text { Current CAPEX }(\text { US } \$)}{\text { Current population }(\text { person })}=U S \$ 8,99$ per person.

The US $\$ 8.99$ per person obtained $X$ forecasted population for 2020, 2030, 2040, and 2050.

Result obtained were US \$1,806.54 million, US \$2,335.25 million, US $\$ 3,018.62$ million and US $\$ 3,901.95$ million respectively.

The benefit-to-cost ratio (BCR) is a financial ratio that is used to determine whether the amount of money made through a project will be greater than the costs incurred in executing the project. Benefit-cost ratios (BCR) of sanitation and water programs in Nigeria from a new global study estimated that the benefit-cost ratio of investments in water supply and sanitation for Nigeria, are to be at least 3.1 times the costs for water supply and at least 2.8 times the costs for sanitation, under the most conservative cost assumptions taking into consideration the improvement of health and time savings ("Global costs and benefits of drinkingwater supply and sanitation interventions to reach the MDG target and universal coverage". World Health Organization. 2012) [13].

Using the estimated benefit-cost ratio of investment in water supply, reported in a new global study to be at least 3.1 times the cost of Nigeria water supply, a calculated benefit-to-cost ratio (BCR) is done for the years from 2020 to 2050 .

\section{Results and discussions}

Geometric population forecast and other indicators were used to determine the economic cost and economic benefit-cost of water supply in the country. It is shown that the country population will continue to increase.

Using the geometric method of population forecast in order determine the continuous growth of people in the country [10].

$$
A=P(1+r)^{n} \text {. }
$$

The formula of this estimation is: $A$ - population at some time in the future that is, nth years' time; $P$ - present or baseline population (190.9 million) of 2018; $r$-average $\%$ increase (geometric mean) that is the annual population growth rate (2.6\%) [17]; $n$-period of projection in decade, i.e. 2020, 2030, 2040 and 2050.

$$
\begin{aligned}
& \text { Population for } 2018=190.9 \text { million person }(1+2.6 \%)^{n} . \\
& \text { Population for } 2020=190.9 \frac{(1+2.6)^{2}}{100},
\end{aligned}
$$

where $n=2020-2018=2$. 
Population for $2020=200.95$ million persons.

Where $n=2030-2018=12$.

$$
\text { Population for } 2030=190.9 \frac{(1+2.6)^{12}}{100} \text {. }
$$

Population for $2030=259.76$ million persons.

Where $n=2040-2018=22$.

$$
\text { Population for } 2040=190.9 \frac{(1+2.6)^{22}}{100} \text {. }
$$

Population $2040=335.77$ million persons.

Where $n=2050-2018=32$.

$$
\text { Population } 2050=190.9 \frac{(1+2.6)^{32}}{100}
$$

Population $2050=434.04$ million persons.

Taking into account the population forecast for 2020, 2030, 2040 and 2050, the CAPEX and benefit-cost ratio of investments in water supply calculated in dependence to the population were 1806.54, 2335.25, 3018.62, 3901.95 and 3.25, $4.22,5.45$, and 7.048 respectively.

$B C R$ calculation. A new global study estimates the benefit-cost ratio of investments in water supply and sanitation for Nigeria, which took into consideration health improvements and time savings. The economic benefits are estimated to be at least 3.1 times the costs for water supply and at least 2.8 times the costs for sanitation, under the most conservative cost assumptions [14].

Using the benefit cost ratio estimated at 3.1 for water supply, the benefit cost ratio for the projection population year 2020 to 2050 can be calculated as;

Year 2018 with the pop 190.9 million $=3.1$.

Year 2020 with the pop 200.95 million $=X$.

$$
X=\frac{3.1 * 200.95}{190.9}=3.26
$$

Table 3

Population, CAPEX and benefit-cost ratio

\begin{tabular}{|c|c|c|c|}
\hline Year & Population, million & CAPEX, US \$ million & Benefit-cost ratio \\
\hline 2018 & 190.9 & 1716.00 & 3.1 \\
\hline 2020 & 200.95 & 1806.54 & 3.26 \\
\hline 2030 & 259.761 & 2335.25 & 4.22 \\
\hline 2040 & 335.775 & 3018.62 & 5.45 \\
\hline 2050 & 434.032 & 3901.95 & 7.05 \\
\hline
\end{tabular}


Figure 3 shows the population projection through 2050. It shows that the population will continue to grow so as the CAPEX. CAPEX requirements cost for forecasted years results showed increase in price as the years go up.

Also, the results on the benefit-cost ratio on water supply has a significant increase in the benefit-cost of investment as the years runs up.

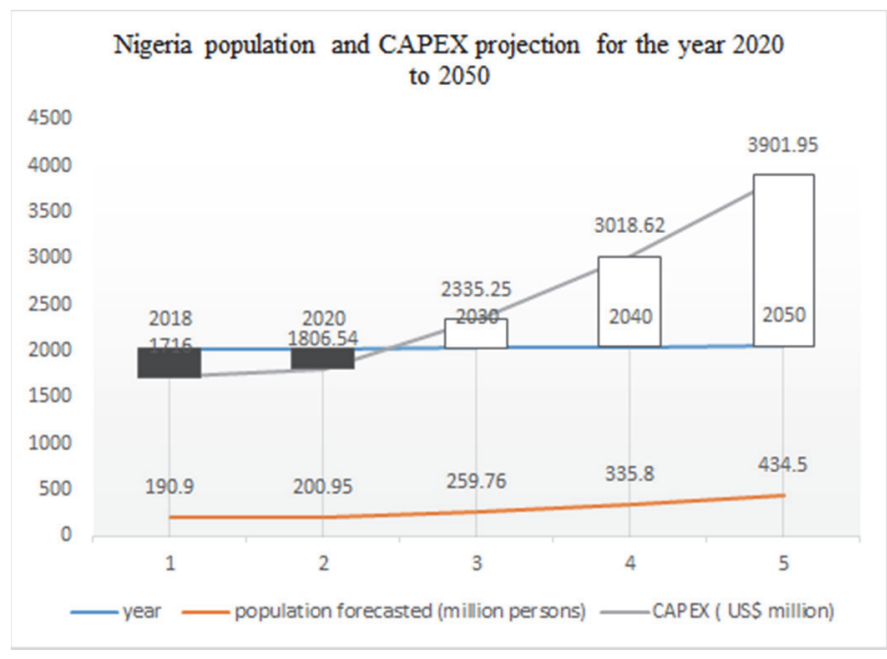

Figure 3. Population forecast and CAPEX

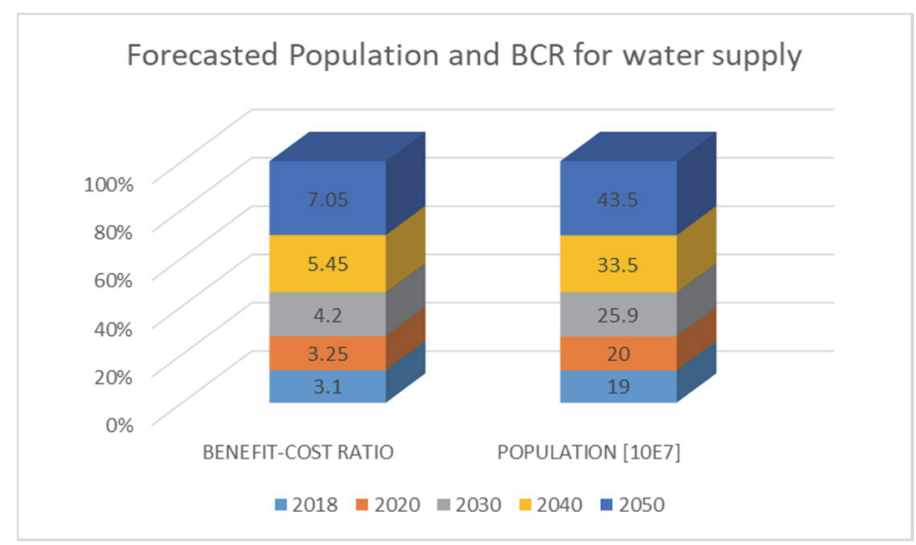

Figure 4. Forecasted population vs BCR

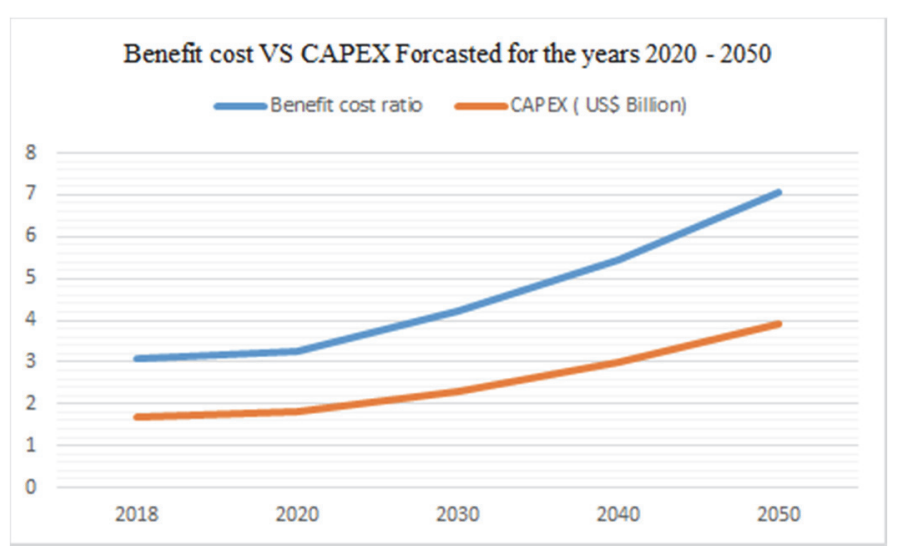

Figure 5. CAPEX and benefit-cost ratio 


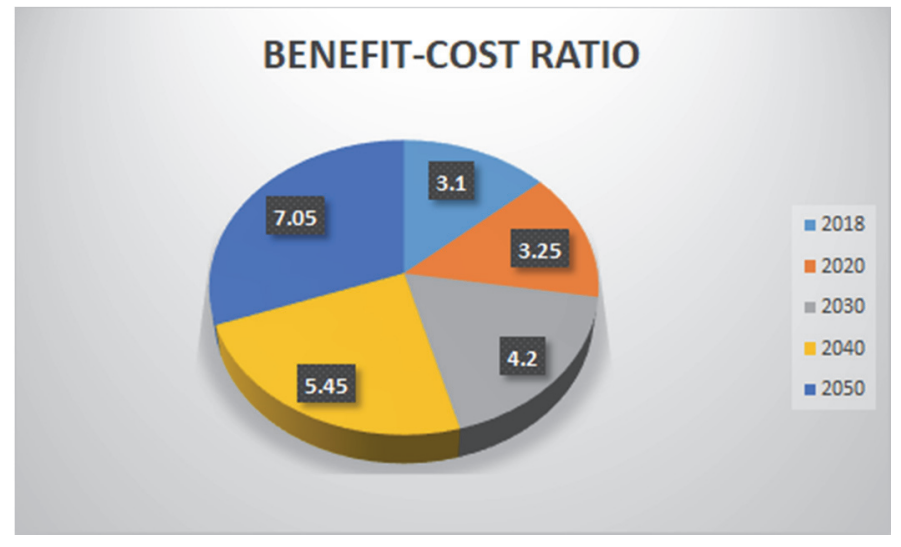

Figure 6. Benefit-cost ratio

The chart in Figure 6 shows the BCR percentages for the calculated years. It shows that the BCR will continue to have a higher BCR for the country in the future years.

\section{Conclusion and recommendations}

Water and effective water supply system management cannot be overemphasized due to its importance for maintaining public health as well as providing and controlling quality and quantity of water. In order to efficiently manage water supply for the country, an adequate funding of the water sector is of utmost importance to ensure improved well-being of the people through regular supply of clean water while also improving the return on investment for the government through payment of utility (water) bill users. The enforcement of environmental regulations needs to be a joint work between government, individual and NGOs. The country could meet with the 2030 Agenda for Sustainable Development Goals if there are immediate and effective actions taken by the government on the CAPEX investment on water supply and enforcement of adopted regulation from the European water regulations and laws or international standards on water regulations.

Water has profound impact on the quality of life indicators and is a major determinant of productivity as well as poverty levels in the country in the sectors such as agriculture, health, education and industry are vulnerable to water supply and sanitation. Unsafe drinking water is still widely used and constitutes severe health problems in the country.

Of the five basic human needs (water, food, health, education, peace) water is a common factor to the other four. Food production as well as most of societies' other socio-economic activities depends on availability of water. Furthermore, the efficiency of food production is currently measured on the basis of a unit increase in the volume of production per unit volume of water [18].

In order to efficiently manage water supply for the country, a quick action is to be taken by the governments, investors, local and international bodies and even the citizen on how to achieve the target on adequate funding of the water sector which is of utmost importance because regular supply of clean water will ensure improved well-being of the people and also improve the return on investment for the investors and government through payment of utility (water) bill users. 
Investment needs in Nigeria are sizable, and considerably greater than current government spending. Spending in Nigeria will need to increase significantly in order to meet the water supply. Investing in sanitation and water can help Nigeria both improve health and tackle economic challenges. Hence, government policy should be not only to increase its own funding, but to catalyze investments from other sources. Also its should implement policies that lead to increased public and private spending on water and sanitation services, especially sanitation, in areas where the country is most off-track. This includes a focus on increasing demand for services among the population through sensitization and marketing campaigns, which will encourage households to invest.

\section{References}

[1] The World Bank Group. Federal Republic of Nigeria: Water Supply \& Sanitation Interim Strategy Note. November 2000 (Accessed 11 April 2012).

[2] Lagos Wastewater Management Office. Available from: http://www.lagoswastewater.org/ ?fbclid $=$ IwAR05s_BMwNnCmTnhCpXu754Uo-U5Azlet9V7hZeXvFmubITB6AJoZ3R_8n4 (Accessed 12 April 2012).

[3] Adelagan JA. The History of Environmental Policy of Water Sources in Nigeria (19602004): The Way Forward. 2004. Available from: http://www.userpage.fu-berlin.de/ flu/akumeu-ibc2004/download (Accessed 12 April 2018).

[4] National Water Policy of Federal Republic of Nigeria. July 2004. p. 3. Available from: ex-twprlegs1.fao.org>docs/pdf/nig158231.pdf (Accessed 12 April 2012).

[5] WHO. Nigeria sanitation, drinking-water and hygiene status overview. Available from: http://www.who.int/water_sanitation_health/monitoring/investments/nigeria-10-nov.pdf (Accessed 10 November 2018).

[6] African Development Bank. The African Development Bank in Action. Activities in the Water and Sanitation Sector in the Federal Republic of Nigeria. February 2012. (Accessed 11 April 2012).

[7] Ite AE, Ufot UF, Ite MU, Isaac IO, Ibok UJ. Petroleum Industry in Nigeria: Environmental Issues, National Environmental Legislation and Implementation of International Environmental Law. American Journal of Environmental Protection. 2016;4(1): 21-37.

[8] WHO \& UNICEF. Joint monitoring programme. Global water supply and sanitation assessment report. Geneva and New York: World Health Organization and United Nations Children's Fund. 2000. Available from: http://www.who. Int/docstore/water sanitation health/Globassessment/GlobalTOC.htm (Accessed 12 April 2018).

[9] The International Benchmarking Network for Water and Sanitation Utilities (IBNET). Available from: https://database.ib-net.org/countries_results?ctry $=22 \& y e a r s=2018,2017$, $2016,2015,2014 \&$ type $=$ indicator\&ent $=$ country \&mult $=$ true\&report $=1 \&$ indicator $=5 \&$ tab le $=$ true \&chart $=$ false \&chartType $=$ column\&lang $=E N \&$ exch $=1$ (Accessed 10 October 2018).

[10] University of Babylon. Population forecasting: what method is best? p. 22. Available from: http://www.uobabylon.edu.iq/uobcoleges/ad_downloads/4_29239_397.pdf (Accessed 11 November 2018).

[11] Adegoroye A. The challenges of environmental enforcement in Africa: The Nigerian experience. Proceedings of the Third International Conference on Environmental Enforcement, Oaxaca, México. 1994;1: 43-54.

[12] The Federal Ministry of Water Resources of Federal Republic of Nigeria: Organization and Activities. Press releases. 2007. Available from: http://waterresources.gov.ng/ category/publications/ (Accessed 11 November 2018).

[13] Hutton G, Haller L. Evaluation of the non-health costs and benefits of water and sanitation improvements at the global level. WHO/SDE/WSH/04.04. Geneva: World Health Organization; 2004. 
[14] African Ministers' Council on Water (AMCOW). Drinking Water Supply and Sanitation in Nigeria: Transforming Funding to AEPA Services. An AMCOW Country Status Overview. 2010.

[15] Guidelines for drinking-water quality. Vol. 3. Surveillance and control of community supplies. $2^{\text {nd }}$ ed. Geneva: World Health Organization; 1997.

[16] National Water Policy of Federal Republic of Nigeria. July 2004. p. 15. Available from: http://extwprlegs1.fao.org/docs/pdf/nig158231.pdf (Accessed 12 April 2012).

[17] IndexMundi. Nigeria - population growth (annual \%). Available from: https://www. indexmundi.com/facts/nigeria/indicator/SP.POP.GROW (Accessed 11 November 2018).

[18] Global Water Partnership. Nigeria stakeholder perspectives on a water goal and its implementation. Available from: https:/www.gwp.org/globalassets/global/about-gwp/ publications/reports/country-consultation-reports/country-consultations-2014/nigerianational-consultation.pdf (Accessed 11 November 2018).

[19] Goldface-Irokalibe IJ. Water Management in Federal and Federal-Type Countries: Nigerian Perspectives. Available from: https://www.africaportal.org/documents/8111/ Joe_Goldface_en.pdf (Accessed 11 November 2018).

[20] The World Bank Group. Nigeria Water Supply, Sanitation, and Hygiene Poverty Diagnostic. The Governance Approach of the World Bank in Nigeria Performance Assessment of the State Water Agencies. Washington. Available from: www.worldbank.org/ water (Accessed 11 November 2018).

\title{
Article history:
}

Received: 26.05 .2019

Revised: 20.06.2019

\section{For citation:}

Balogun OR, Redina MM. Water supply regulation in Nigeria: problems, challenges, solutions and benefits. RUDN Journal of Ecology and Life Safety. 2019;27(1): 65-81. http://dx.doi.org/10.22363/2313-2310-2019-27-1-65-81

\section{Bio notes:}

Olajumoke Rukayat Balogun - masters' student of an Economic of Natural Resource Management, Faculty of Ecology, Peoples' Friendship University of Russia (RUDN University). Contact information: e-mail: balogunolajumoke23@gmail.com

Margarita M. Redina - Doctor of Economic Sciences, Associate Professor, Dean of the Faculty of Ecology, Head of the Department of Applied Ecology, Peoples' Friendship University of Russia (RUDN University). Contact information: E-mail: redina-mm@rudn.ru

Научная статья

\section{Регулирование водоснабжения в Нигерии: проблемы, задачи, решения и выгоды}

\author{
О.Р. Балогун, М.М. Редина \\ Российский университет дружбы народов \\ Российская Федерация, 117198, Москва, ул. Миклухо-Маклая, 6
}

\begin{abstract}
Аннотация. Нигерия известна своей богатой растительностью и тропической погодой и наделена избыточными водными ресурсами, несмотря на это она все еще сталкивается с проблемами обеспечения всей страны чистой водой и во многом зависит от альтер-
\end{abstract}


нативных систем водоснабжения, таких как колодцы, скважины и реки. Однако альтернативные системы водоснабжения не являются эффективными и недостаточны для систем водоснабжения, особенно в стране с большим населением, в связи с чем водоснабжение имеет нерегулярный характер. Законы об управлении водными ресурсами также слабы и в основном не соответствуют сегодняшним стандартам и потребностям. Правительство не уделяет должного внимания надлежащему управлению и сохранению услуг и ресурсов водоснабжения. По этой причине важно выявить фактор, который препятствует осуществлению правил водоснабжения, и предложить решение проблемы. В стремлении понять последствия внедрения и обеспечения строгого регулирования в области водоснабжения с целью надлежащего водоснабжения страны, мы сравниваем прогнозируемую численность населения с инвестиционными капиталовложениями (САРЕХ) в водоснабжение в соответствии с целями развития тысячелетия (ЦРТ +). Результаты показывают, что в предстоящем году страна получит значительную выгоду от инвестиций и обеспечения регулярного водоснабжения благодаря наличию рабочих мест и доходов, получаемых за счет коммунальных вод, затрачивая при этом меньше средств на эпидемические болезни, передаваемые через воду, при этом улучшая жизнь и здоровье своих граждан.

Ключевые слова: водоснабжение; регулирование; внедрение; инвестиции; льготы

\section{Список литературы}

[1] Federal Republic of Nigeria: Water Supply \& Sanitation Interim Strategy Note / The World Bank Group. November 2000 (дата обращения: 11.04.2012).

[2] Lagos Wastewater Management Office. URL: http://www.lagoswastewater.org/?fbclid= IwAR05s_BMwNnCmTnhCpXu754Uo-U5Az1 et9V7hZeXvFmubITB6AJoZ3R_8n4 (дата обращения: 12.04.2012).

[3] Adelagan J.A. The History of Environmental Policy of Water Sources in Nigeria (1960-2004): The Way Forward. 2004. URL: http://www.userpage.fu-berlin.de/flu/ akumeu-ibc2004/download (дата обращения: 12.04.2018).

[4] National Water Policy of Federal Republic of Nigeria. July 2004. P. 3. URL: ex-twprlegs1.fao.org〉docs/pdf/nig158231.pdf (дата обращения: 12.04.2012).

[5] WHO. Nigeria sanitation, drinking-water and hygiene status overview. URL: http:// www.who.int/water_sanitation_health/monitoring/investments/nigeria-10-nov.pdf (дата обращения: $10.11 . \overline{2} 018)$.

[6] The African Development Bank in Action. Activities in the Water and Sanitation Sector in the Federal Republic of Nigeria / African Development Bank. February 2012. (дата обращения: 11.04.2012).

[7] Ite A.E., Ufot U.F., Ite M.U., Isaac I.O., Ibok U.J. Petroleum Industry in Nigeria: Environmental Issues, National Environmental Legislation and Implementation of International Environmental Law // American Journal of Environmental Protection. 2016. Vol. 4. No. 1. Pp. 21-37.

[8] WHO \& UNICEF. Joint monitoring programme. Global water supply and sanitation assessment report. Geneva and New York: World Health Organization and United Nations Children's Fund. 2000. URL: http://www.who. Int/docstore/water_sanitation health/Globassessment/GlobalTOC.htm (дата обращения: 12.04.2018).

[9] The International Benchmarking Network for Water and Sanitation Utilities (IBNET). URL: https://database.ib-net.org/countries_results?ctry=22\&years $=2018,2017,2016,2015$, $2014 \&$ type $=$ indicator $\&$ ent $=$ country \&mult $=$ true \&report $=1 \&$ indicator $=5 \&$ table $=$ true $\& \mathrm{ch}$ art=false\&chartType=column\&lang=EN\&exch=1 (дата обращения: 10.10.2018).

[10] University of Babylon. Population forecasting: what method is best? P. 22. URL: http://www.uobabylon.edu.iq/uobcoleges/ad_downloads/4_29239_397.pdf. (дата обращения: 11.11.2018). 
[11] Adegoroye A. The challenges of environmental enforcement in Africa: The Nigerian experience // Proceedings of the Third International Conference on Environmental Enforcement, Oaxaca, México. 1994. Vol. 1. Pp. 43-54.

[12] The Federal Ministry of Water Resources of Federal Republic of Nigeria: Organization and Activities. Press releases. 2007. URL: http://waterresources.gov.ng/category/publications/ (дата обращения: 11.11.2018).

[13] Hutton G., Haller L. Evaluation of the non-health costs and benefits of water and sanitation improvements at the global level. WHO/SDE/WSH/04.04. Geneva: World Health Organization, 2004.

[14] Drinking Water Supply and Sanitation in Nigeria: Transforming Funding to AEPA Services. An AMCOW Country Status Overview / African Ministers' Council on Water (AMCOW). 2010.

[15] Guidelines for drinking-water quality. Vol. 3. Surveillance and control of community supplies. $2^{\text {nd }}$ ed. Geneva: World Health Organization, 1997.

[16] National Water Policy of Federal Republic of Nigeria. July 2004. P. 15. URL: http:// extwprlegs1.fao.org/docs/pdf/nig158231.pdf (дата обращения: 12.04.2012).

[17] IndexMundi. Nigeria - population growth (annual \%). URL: https://www.indexmundi.com/ facts/nigeria/indicator/SP.POP.GROW (дата обращения: 11.11.2018).

[18] Nigeria stakeholder perspectives on a water goal and its implementation / Global Water Partnership. URL: https://www.gwp.org/globalassets/global/about-gwp/publications/reports/ country-consultation-reports/country-consultations-2014/nigeria-national-consultation.pdf (дата обращения: 11.11.2018).

[19] Goldface-Irokalibe I.J. Water Management in Federal and Federal-Type Countries: Nigerian Perspectives. URL: https://www.africaportal.org/documents/8111/Joe_Goldface_en.pdf (дата обращения: 11.11.2018).

[20] Nigeria Water Supply, Sanitation, and Hygiene Poverty Diagnostic. The Governance Approach of the World Bank in Nigeria Performance Assessment of the State Water Agencies / The World Bank Group. Washington. URL: www.worldbank.org/water (дата обращения: 11.11.2018).

\section{История статьи:}

Дата поступления в редакцию: 26.05.2019

Дата принятия к печати: 20.06.2019

\section{Для цитирования:}

Balogun O.R., Redina M.M. Water supply regulation in Nigeria: problems, challenges, solutions and benefits (Регулирование водоснабжения в Нигерии: проблемы, задачи, решения и выгоды) // Вестник Российского университета дружбы народов. Серия: Экология и безопасность жизнедеятельности. 2019. Т. 27. № 1. С. 65-81. http:// dx.doi.org/10.22363/2313-2310-2019-27-1-65-81

\section{Сведения об авторах:}

Оладжумоке Рукайат Балогун - студентка магистратуры экологического факультета, Российский университет дружбы народов. Контактная информащия: e-mail: balogunolajumoke23@gmail.com

Редина Маргарита Михайловна - доктор экономических наук, доцент, декан экологического факультета, заведующая кафедрой прикладной экологии, Российский университет дружбы народов. Контактная информаџия: e-mail: redina-mm@rudn.ru 